\title{
Ontario Interns Fight Back: Modes of Resistance Against Unpaid Internships
}

\author{
William Webb \\ Wilfrid Laurier University, Waterloo, Canada, webb7140@mylaurier.ca
}

\begin{abstract}
In this article I report on three ways that interns and those sympathetic to their plight are opposing unpaid internships, focusing on the Canadian province of Ontario as a case. First, I analyze the ways that interns engage in social activism to raise awareness about problems with unpaid internships. Second, I examine several lawsuits that interns have waged against companies in an attempt to secure back pay. Third, I analyze the Ontario Ministry of Labour's response to the growing concerns surrounding unpaid internships, and recent proposals that aim to strengthen governmental regulations. Arguing that possibilities for change have arisen largely due to the efforts of interns themselves, I conclude each section by noting some of the strengths and limitations afforded by each type of resistance.
\end{abstract}

Keywords: unpaid Internships, internships, Ontario, Labour, Canada, social activism, lawsuits, litigation, policy, Ontario Ministry of Labour

Acknowledgement: I would like to thank Greig de Peuter, Enda Brophy, and Nicole Cohen for their helpful comments on this article

\section{Introduction}

Unpaid internships have recently been subject to a host of social and ethical criticisms. Scholars and activists have argued that unpaid internships are often unfair, illegal, exploitative of vulnerable demographics, and negatively impact social mobility (de Peuter et al. 2012; Oakley 2013; Perlin 2011; Siebert and Wilson 2013). In light of these problems, many are challenging the status of unpaid internships. In this article I report on three ways that interns and those sympathetic to their plight are opposing unpaid internships in Ontario. First, I explore the ways that intern organizations in Ontario are raising awareness about problems with unpaid internships. Next, I examine several lawsuits that interns have waged against companies in an attempt to secure back pay, namely, Girex Bancorp v Hsieh, Sandhu v Brar, and Patel $v$ Bell Mobility Inc. Finally, I explore the Ontario Ministry of Labour's response to the growing concerns surrounding unpaid internships and proposals that aim to strengthen governmental regulations. Arguing that possibilities for change have arisen largely due to the efforts of interns themselves, I conclude each section by noting some of the strengths and limitations afforded by each type of resistance.

\section{Social Activism and Intern Organizations}

Over the past few years, interns have spearheaded a movement to secure pay and gain respect for their work. Interns have commonly used the following tactics to oppose unpaid internships in Ontario: informing and educating the public, naming and shaming those who offer unpaid internships, and lobbying for the reform and enforcement of existing labour laws.

Intern-led groups such as the Canadian Intern Association (CIA) and Students Against Unpaid Internship Scams (SAUIS) offer resources that address a variety of intern-related issues. Both of these organizations were formed in order to improve working conditions for interns: the Canadian Intern Association is a federal not-for-profit organization that was founded in 2012 by a group of students, whereas SAUIS is a provincial organization that operates in Ontario and was formed by a group of students, and youth and labour activists in 2013. Each of these groups outline Ontario's internship laws and offer commentary in an attempt to 
make understanding the law more accessible to students, young workers, and employers. These activist groups also highlight several of the problems associated with unpaid internships in Ontario and Canada, such as exploitation, higher unemployment rates, and "socioeconomic, gender, and intergenerational inequality" (Canadian Intern Association 2014a). The CIA has also partnered with Master's students at the University of Victoria to help fill the gap in research on internships in both Ontario and Canada (Attfield and Couture 2014). In addition to their strong online presence, intern activist groups have publicized intern issues by hosting events and meetings, and maintaining a presence on mainstream Canadian news media, such as CBC, CTV, The Toronto Star, and Maclean's magazine. These activist groups have found support from blogs by Ontario lawyers, such as Youth and Work, Law of Work, and Wise Law Blog, which offer a more in-depth analysis of legal issues, but also provide a compilation of legal, governmental, and NGO resources to aid interns in pursuing social and legal modes of resistance against unpaid internships.

In Ontario, critics of unpaid internships have participated in "naming and shaming" employers that offer unjust or illegal internships (de Peuter et al. 2012). For example, the Canadian Intern Association has a 'Wall of Shame' on its website, where illegal internships are identified and criticized from legal and ethical perspectives, and a 'Wall of Fame,' where employers are praised for their legal and ethical internship practices. While its website offers analytical depth, the Canadian Intern Association, alongside SAUIS and Toronto labour lawyer Andrew Langille, have used social media, namely Twitter, to name and shame a wider range of employers who use unpaid interns. One benefit of naming and shaming online is that interns may remain anonymous, and thus avoid negative social and financial repercussions that may otherwise accompany criticizing their own or other employers (ibid). While it is difficult to determine the effectiveness of these tactics, they at least serve the purpose of raising awareness, and at most have caused some companies to remove their advertisements for unpaid internships. Nevertheless, name and shame tactics have had some success in provinces that have stricter internship laws, such as British Columbia. For instance, in 2013, the social media website Reddit posted a thread about an illegal internship offered by HootSuite. The online backlash against the Vancouver-based social media company was enough to make the company issue an apology and state that it would reform its intern program to comply with the law (Reddit 2013).

Intern activists have also lobbied for the reform and enforcement of existing regulations. ${ }^{1}$ SAUIS and the Canadian Intern Association have submitted proposals that urge the Ontario Ministry of Labour (MOL) to review existing laws on unpaid internships. Moreover, SAUIS and the Youth Alliance for Progress (YAP) ${ }^{2}$ offer a template e-mail that demands a review of labour law (the email is addressed to the Premier of Ontario and the MOL). SAUIS and YAP have also started petitions that call the MOL to review existing labour law; these petitions have received over 1,000 and 100 signatures, respectively. Others, such as the Canadian Intern Association, have met with federal party leaders, Members of Parliament, and Members of Provincial Parliament to voice their concerns about unpaid internships. Without reforming and enforcing existing labour laws, the influence of intern activists will likely be limited; activists may serve as watchdogs for instances of illegal internships, but their bite is limited without increased support from the MOL.

Social activism, in contrast with litigation and policy proposals, offers several advantages as a means for those seeking to change the status quo of internships in Ontario. For one, activism has been a valuable and pragmatically necessary starting point for changing the status of unpaid internships by raising awareness about the social, ethical, and legal issues surrounding internships. Activist groups also provide a place for connectivity, support, and visibility for those who are experiencing or have experienced the negative consequences of an unpaid internship. Additionally, social media provides an opportunity for anonymity that can

\footnotetext{
${ }^{1}$ I examine the content of these proposals in greater depth in the final section of this article.

${ }^{2}$ Founded in 2013, YAP is a not-for-profit organization that is committed to intergenerational equality in Canada.
} 
help shield interns from negative repercussions that may accompany speaking out against unpaid internships.

The veil of anonymity, however, only goes so far. The pressures facing young people who want to enter into internship-saturated industries may discourage them from participating in broader intern activism, including signing petitions, going to events, connecting with social media linked to their identity, or becoming members of intern activist organizations. These pressures are especially prevalent in the cultural industries, where unpaid internships are now industry standards. In her study of young workers in the cultural industries, Angela McRobbie notes that the "emphasis on presentation of self is incompatible with a contestatory demeanour" $(2002,523)$. Simply put, "[i]t's not 'cool' to be difficult" (ibid). In addition, young workers in Ontario face a high unemployment rate, which fluctuated between 16 percent and 17.1 percent in 2013 (Geobey 2013). Given that the odds are already stacked against them, young people may not want to participate in activities that could further limit the possibility of securing employment. Fortunately for young workers, however, support for intern activist organizations extends beyond interns themselves, and includes efforts from lawyers, activists, academics, and former interns.

Interns also face issues of inter-group and intra-group solidarity. Regarding the former, Ontario intern organizations are primarily concerned with the internship problem itself, and are less focused on engaging in a broader type of solidarity on a legislative level. Given that several of the work issues associated with interns, such as social and financial insecurity, are also present in other types of precarious work (de Peuter 2011; Vosko 2006), it might be beneficial for interns to formally unite with other workers in precarious employment situations, such as freelancers, the self-employed, and contract workers. To their credit, intern activists often use rhetoric that characterizes unpaid internships as precarious work, and engage in meaningful discussions with other workers in precarious employment. The issue here is not merely descriptive, but also conceptual; it is difficult to arrive at a collective labour politics that garners the benefits of including many different types of voices, while also not sacrificing the specificity of issues faced in different sectors and types of work. Solidarity is also difficult to develop due to the spatial and temporal fragmentations among interns. Since internships typically last a short period of time, and organizations only employ a limited number of interns, interns face difficulty in connecting and arriving at common interests. Nevertheless, activists are using social media, websites, and events to help overcome some of these fragmentations. Despite these attempts to bridge the temporal and spatial gaps, other issues of fragmentation still arise. For instance, those interns who have since secured jobs may not wish to support present internship movements at the expense of damaging their professional reputation or career. There are also differing views about unpaid internships amongst young workers and interns themselves; some view internships as unfair, while others view unpaid internships as necessary, normalized, or legitimate (Siebert and Wilson 2013).

\section{Litigation}

Although there are relatively few cases in Ontario where interns have used litigation to claim back their pay, most of the cases have been ruled in favour of the intern. At present, the leading case on internships in Ontario is Girex Bancorp $v$ Hsieh, in which two unpaid interns were successful in claiming back pay for the work they completed at Girex Bancorp (Langille 2011). Despite originally agreeing to be unpaid, the two interns were able to secure pay because the work they completed violated the criteria for what constitutes a legal unpaid internship as outlined in ss. 1(2) of Ontario's Employment Standards Act (ESA). In particular, the interns were eligible for receiving back pay because they did not receive training similar to that provided by a vocational school, they did not benefit from either the training they received or the work they completed, and the work they completed primarily benefited the employer (Girex Bancorp 2004). Similar issues were present in the more recent case of Sandhu $\checkmark$ Brar, where Harpreet Brar filed a claim against Chamkaur Singh Sandhu and his father Jagrup Singh Sandhu after initially agreeing to work an unpaid co-op position as a computer technician. Like Hsieh, Brar's position breached the ESA because the tasks he performed 
were for the benefit of the employer, they did not benefit Brar, and Brar did not receive training similar to that offered at a vocational school (Sandhu v. Brar 2013). These two cases are beneficial for the interests of unpaid interns not only because they serve to illustrate and publicize some of the legal issues surrounding unpaid internships in Ontario, but also because the legal precedent they have set is in favour of unpaid interns. The success of these cases may encourage other interns to pursue litigation, and may discourage employers from offering unpaid internships due to the costs of litigation and negative publicity.

Not all unpaid internship cases have been as straightforward. In Patel v Bell Mobility Inc., Jainna Patel filed a labour complaint against Bell's Professional Management Program in Toronto. Patel claims that she did work that would have normally been completed by paid employees, and did not benefit from the work experience or training (Oved 2013). While the work that Patel completed violates Ontario's ESA, Bell Mobility Inc. falls under federal jurisdiction and is governed by the Canadian Labour Code (CLC). Accordingly, a federal labour inspector examined Patel's case, concluding that she was not eligible for back pay because the modules she participated in were "not based on the needs of Bell at any given time and Bell did not use the work prepared by [Patel] to support or benefit its business operations" (Oved 2013). The inspector also claimed that Patel was aware the program was unpaid and that there was no guarantee of employment after the training was complete. Unfortunately for Patel, the CLC has no exclusions for interns, and consequently is less clear about the legal status of internships (Canadian Intern Association 2014b). Although Patel's claim was initially rejected, she appealed the decision in the hopes of securing back pay and proving the point that Bell Mobility's program is illegal, unfair, and exploitative. Less than one year after Patel filed her appeal, Bell cancelled its unpaid internship program (Bell's official statement failed to provide reasons why the program was terminated and whether the termination would be permanent). In response, Patel's lawyer, Tim Gleason, noted that Bell likely cancelled its program in part due to concerns about "ongoing liability" (Goodman 2014).

While there is hope for interns who want to use litigation for securing back pay, there are risks that accompany this type of resistance. One of the greatest difficulties is that the costs of pursuing a lawsuit may outweigh the potential benefits. Along with litigation come a host of resources that one has to invest, including time, money, and intellectual and emotional effort. Given that those who work unpaid internships are often young, it is likely that they may either simply not have the resources to pursue litigation or may want to commit their resources to advancing their career in a more substantive way. The recuperation of minimum or low wages for a relatively short period of time and the rectification of injustice may also not be sufficient to outweigh the risk of committing the time, energy, and expense. While there are a number of legal services that offer free consultations to young workers and interns, many young workers do not have the luxury of being able to afford lawyers without being taken on pro bono. Even if interns find legal representation, it is improbable that their pockets run as deep as their employer's, and cases may be dropped due to prolonged resource depletion. In addition, interns may be reluctant to pursue litigation because it may harm their professional reputation. If one's reputation and connections are a considerable part of why one undertakes an internship (Attfield and Couture 2014; Siebert and Wilson 2013), it is unlikely they will sabotage these goals to receive a small amount of pay that they might not have expected to receive in the first place. This issue is exacerbated given that interns run the risk of being blacklisted if they pursue litigation; blacklisting is a practice that serves to deny entry into a particular industry to those who have openly opposed the interests of other employers in the same industry (Langille 2012a; SAUIS 2014).

One alternative to pursuing litigation individually is to form a class action lawsuit against employers who have offered illegal unpaid internships. Langille suggests that a class action lawsuit is waiting to happen in Ontario: "the environment exists where a class-action lawsuit could possibly work, the trick is you have to find the people... but they're out there" (2012b). While a class action lawsuit may help to ease some of the aforementioned challenges, it may be difficult to find individuals to represent given the temporal and spatial fragmentation of internships. Trying to arrange a successful class action lawsuit may also be difficult given that the type of work interns perform and the companies for which they work are diverse. This 
issue surfaced in the Harper's Bazaar class action lawsuit in the United States, which was dismissed on the grounds that the work completed by the plaintiffs was too dissimilar (Greenfield 2013).

\section{Government Involvement}

In June 2011, the Ontario Ministry of Labour (MOL) introduced the first fact sheet on internships. The need to produce a fact sheet has arisen alongside the increase in number of internships, demands by activists, and relevant case law. At the core of internship-related laws is the MOL's commitment to "ensuring fairness and protecting young workers" (2014). From this basic principle, the MOL notes that it is illegal to offer an unpaid internship unless it meets all of the following criteria:

1. The training is similar to that which is given in a vocational school. 2 . The training is for the benefit of the individual. 3. The person providing the training derives little, if any, benefit from the activity of the individual while he or she is being trained. 4. The individual does not displace employees of the person providing the training. 5 . The individual is not accorded a right to become an employee of the person providing the training. 6 . The individual is advised that he or she will receive no remuneration for the time that he or she spends in training. (Ontario Ministry of Labour 2014)

One exception to these criteria is work that is performed "under a program approved by a college of applied arts and technology or a university" (ibid). While this factsheet is a step in the right direction, many argue there is a need for greater government involvement with intern-related issues. In what follows, I highlight three of the central concerns that have been raised: education and research, strengthening enforcement standards, and reviewing existing labour laws. These proposals to the MOL have come in the form of pre-budget recommendations from the Youth Alliance for Progress, Students Against Unpaid Internship Scams, the Canadian Intern Association, and Andrew Langille, a Private Member's Bill from Member of Provincial Parliament Peggy Sattler, ${ }^{3}$ and a Government Bill from then-Ontario Labour Minister Yasir Naqvi. I also discuss Members of Parliament Andrew Cash and Laurin Liu's Private Members Bill, the Intern Protection Act, which has been introduced at the federal level.

Students Against Unpaid Internship Scams, the Canadian Intern Association, Langille, and Sattler recommend that the MOL should raise awareness about the law on unpaid internships. Together these proposals suggest that the MOL should develop an education campaign that includes informing all relevant parties through advertising, the use of social media, and "the development of audience-specific educational materials" (Langille and Mandryk 2013). Furthermore, these proposals, alongside Sattler's Bill 22 and Naqvi's Bill 146, recognize the lack of research on unpaid internships in Ontario and Canada, and propose that Statistics Canada and the MOL conduct data collection in order to better develop labour laws and enforcement tactics. Included in the areas requested for data collection are the school to labour market transition, "the number of paid and unpaid internships, whether they are part of a formal educational program," and identifying which industries offer the most internships (Canadian Intern Association 2014c, 5).

Although the foregoing proposals request that the MOL educate the public about internship laws, they fail to explicitly recommend that the MOL raise awareness about social issues surrounding unpaid internships; many of the problems with unpaid internships go beyond mere legality and deal with issues of race, gender, exploitation, age, and social mobility (de Peuter et al. 2012; Oakley 2013; Perlin 2011; Seibert and Wilson 2013). While it is debatable whether certain social issues fall outside the domain of government responsibility, the proposed educational campaign may benefit from this kind of supplementation. Providing this

\footnotetext{
${ }^{3}$ This bill was originally introduced by then-Member of Provincial Parliament Jonah Schein, and was later reintroduced by Sattler in July 2014 after Schein was not re-elected in Ontario's 2014 election.
} 
background on internships would help strengthen intern efforts by highlighting wider points of connectivity with their cause at the level of race, gender, and class. Furthermore, these proposals are scarce on putting any onus on employers to (at least minimally) inform their interns about the legal status of internships in Ontario. One exception is Sattler's Bill 22, which calls for an 'interns' bill of rights poster that employers would be required to post in the workplace" (Sattler 2014). While having a poster in the workplace would help to bring visibility to the issue, the MOL could place further responsibility on employers. For instance, the MOL could require employers to include a clause in internship contracts that states the intern was explicitly made aware of and understands the laws on unpaid internships. Placing minimal responsibility on employers to inform their interns has the potential to help promote, and start to normalize, legal and fair standards for internships in the workplace.

Second, SAUIS, the CIA, YAP, and Langille all note that the enforcement of internshiprelated laws is inadequate, and demand proactive enforcement standards. The MOL responded to some of these concerns in 2013 by investing $\$ 3$ million to hire and train 20 officers to conduct 1,400 labour inspections annually. This initiative found recent success with the termination of two illegal internship programs at Toronto-based magazines The Walrus and Toronto Life. Despite this success, none of the officers are specifically dedicated to inspect internships, and only "a very limited number of sectors were selected for inspection blitzes regarding vulnerable workers and unpaid wages" (Canadian Intern Association 2014c, 4). Accordingly, activists propose that the MOL assign officers to inspect internship programs, target high-risk employers, and increase the number of inspections. They also recommend that the MOL strengthen enforcement tactics by developing an anonymous tips hotline and by targeting unpaid internships that are advertised online. While these proactive tactics would help ease the present burden that interns face with reporting illegal internships, a better long-term enforcement solution is needed. One possible strategy is a permit system that would require internships to be registered with either a vocational school or the MOL (Doorey 2013; SAUIS 2014). Central to the permit system would be a code of conduct that clearly outlines criteria for fair internships; either a vocational school or the MOL would monitor and oversee internships to ensure the code of conduct is followed. Since the permit system would have clearly established guidelines and institutions overseeing the internship, enforcement would be more reliable.

Third, these proposals and bills seek to change labour laws to better reflect the concerns of interns, focusing on the areas of workplace rights, litigation and fines, and exclusions. Receiving support from intern activists, Cash and Liu's Intern Protection Act would allow unpaid interns who work in federally regulated industries to qualify for workplace standards and protections (Cash 2014). Their bill addresses a critical loophole in federal legislation, which is presently unclear about whether interns qualify for these employment rights. As exemplified by Patel $v$ Bell Mobility Inc., this loophole has been an enabling condition for hundreds of unpaid internships in Bell's Professional Management Program alone. While the Intern Protection Act would help crack down on these federally regulated organizations, it fails to address the two other primary concerns that were raised in proposals to the MOL: awareness and enforcement. If the Intern Protection Act passes, Cash and Liu should draw from the policy groundwork currently being laid in Ontario in order to avoid a number of enforcement-related issues that Ontario has encountered in the past; a proactive approach that extends beyond simply strengthening labour laws would help to reduce the number of (illegal) unpaid internships in federally regulated industries.

In Ontario, Naqvi's Bill 146 proposes to give unpaid interns equal protections as paid employees in the Occupational Health and Safety Act. Sattler's bill would also ensure greater rights for interns, including a regular workday, eating periods, holidays, and the right to file a complaint with the MOL. The bill would change the time limit for filing a complaint for back pay from six months to two years, and remove the $\$ 10,000$ cap on claiming unpaid wages. In addition to loosening these legal restrictions, the Youth Alliance for Progress notes that the current penalty for offering an unpaid internship is grossly inadequate. Instead of the existing fine- $\$ 250$ for the first offence-YAP argues that the MOL should charge "corporations who break the law a meaningful fine, one that costs more than the value of free work they re- 
ceive" (2013). Additionally, the Canadian Intern Association recommends amending exclusions pertaining to trainees, professionals, and students. The association states that the trainee exclusion in the ESA should be removed due to the definitional ambiguity it raises with interns; removing this exclusion would entitle interns to "minimum wage unless they are part of a formal educational program or ... [a] professional exclusion"4 (Canadian Intern Association $2014 \mathrm{c}, 6)$. The association also recommends that there should be workplace guidelines for internships that come under the student exclusion, such as the six criteria for trainees, and a cap on the number of unpaid hours that can be worked per semester.

Alongside these changes, the MOL needs to address the structural employment changes that accompany unpaid internships. More specifically, the fourth criterion of the MOL's policy on internships inadequately reflects the broader economic shift that is accompanying the rise of unpaid internships. While research on internships is limited, findings indicate not only that unpaid internships tend to replace paid jobs, such as summer jobs and entry-level positions, but they also take away new growth positions (Langille and Mandryk 2013; Perlin 2011; Seibert and Wilson 2013). Since unpaid internships are replacing paid positions on a structural level, unpaid internships as a type of work breach the fourth criterion. If the MOL wishes to remain consistent, they need to enact stricter laws that address this employment shift.

While these issues need to be addressed by the MOL, one unavoidable pitfall of a comprehensive legislation review is that the educational campaign will be further delayed; it would be counterintuitive to launch a campaign informing people about the laws on unpaid internships until the comprehensive review would be completed. The temporal hurdle here should not be undersold. Legislation takes a considerable amount of time and effort to prepare and pass, let alone publicize and enforce in an effective manner. Moreover, policies are "rooted in having an understanding of the dimensions of an issue and [this] presents a barrier to formulating appropriate regulatory responses" (Langille 2013). That is, the legislative proposals and bills on internships face the obstacle of trying to succeed with a limited amount of research on internship-related issues. Nonetheless, changing labour laws to better reflect the needs of interns appears necessary if the problems they face are to be properly addressed.

\section{References}

Attfield, James and Isabelle Couture. 2014. An Investigation into the Status and Implications of Unpaid Internships in Ontario. Master's Thesis, University of Victoria.

Bill 170, Employment Standards Amendment Act (Greater Protection for Interns and Vulnerable Workers), 2nd Sess., 40th Legislature, Ontario 63 Elizabeth II, 2014. http://www.ontla.on.ca/bills/bills-files/40 Parliament/Session2/b170.pdf.

Bill 146, Stronger Workplaces for a Stronger Economy Act, 2nd Sess., 40th Legislature, Ontario 63, Elizabeth II, 2013. http://www.ontla.on.ca/bills/bills-files/40 Parliament/Session2/b146.pdf.

Cash, Andrew. 2014. Read the Text of the Intern Protection Act. Accessed September 10, 2014. http://andrewcash.ca/read-the-text-of-the-intern-protection-act/.

Canadian Intern Association. 2014a. About Us. Accessed May 24, 2013. http://www.internassociation.ca/about/.

Canadian Intern Association. 2014b. What is the Law? Accessed May 24, 2013. http://www.internassociation.ca/what-is-the-law/.

Canadian Intern Association. 2014c. Pre-Budget Consultations. Accessed May 24, 2014. http://www.internassociation.ca/wp-content/uploads/2014/02/CIA-Ontario-Budget-Submissions.pdf.

de Peuter, Greig. 2011. Creative Economy and Labor Precarity: A Contested Convergence. Journal of Communication Inquiry 35 (4): 417-425.

de Peuter, Greig, Nicole Cohen and Enda Brophy. 2012. Interns, Unite! You Have Nothing to LoseLiterally. Briarpatch, November 9.

Doorey, David. 2013. A Three Step Solution for Tackling the Problem of Unpaid Internships in Ontario. Accessed November 5, 2013. http://lawofwork.ca/?p=7123.

Geobey, Sean. 2013. The Young and the Jobless: Youth Unemployment in Ontario. Canadian Centre for Policy Alternatives. Accessed May 24, 2014.

\footnotetext{
${ }^{4}$ The Canadian Intern Association also advocates for removing the professional exclusion in order that those entering a profession are guaranteed a minimum wage.
} 
http://www.policyalternatives.ca/sites/default/files/uploads/publications/Ontario\%200ffice/2013/09/ Young_and_jobless_final3.pdf.

Girex Bancorp v. Hsieh [2004] ON L.R.B. 24679.

Goodman, Lee-Anne. 2014. Bell Mobility Scraps Unpaid Internship Program. The Globe and Mail, August 8.

Greenfield, Rebecca. 2013. Class Action or Not, the Unpaid Intern Lawsuit at Hearst Will Go On. The Atlantic Wire, May 9.

Langille, Andrew. 2011. The Legality of Unpaid Internships in Ontario. Accessed May 24, 2014. http://www.youthandwork.ca/2011/07/unpaid-internships-in-ontario.html.

Langille, Andrew. 2012a. Scaling Asshole Mountain (and Other Adventures in Nerdistan). Accessed May 24, 2014. http://www.youthandwork.ca/2012/10/scaling-asshole-mountain-and-other.html.

Langille, Andrew. 2012b. Are Class Action Lawsuits Over Unpaid Internships Coming to Canada? Accessed May 24, 2014. http://www.youthandwork.ca/2012/03/are-class-action-lawsuits-overunpaid.html.

Langille, Andrew. 2013. Why Canada Needs Better Labour Market Data and the Canadian Internship Survey. Accessed May 24, 2014. http://www.youthandwork.ca/2013/10/why-canada-needs-betterlabour-market.html.

Langille, Andrew. 2014. Pre-Budget Consultations. Accessed May 24, 2014. https://www.academia.edu/6302484/Recommendations_Re_Regulation_of_Unpaid_Internships_In Ontario.

Langille, Andrew and Josh Mandryk. 2013. Ontario Must Take Urgent Action on Unpaid Internships. The Toronto Star, November 4.

McRobbie, Angela. 2002. Clubs to Companies: Notes on the Decline of Political Culture in Speeded Up Creative Worlds. Cultural Studies 16 (4): 516-531.

Oakley, Kate. 2013. Making Workers: Higher Education and the Cultural Industries Workplace. In Cultural Work and Higher Education, edited by Daniel Ashton and Caitriona Noonan, 25-44. New York: Palgrave Macmillan.

Oved, Marco. 2013. Unpaid Intern's Claim for Wages Rejected. The Toronto Star, October 24.

Ontario Ministry of Labour. 2014. Are Unpaid Internships Legal in Ontario? Accessed May 30, 2014. http://www.labour.gov.on.ca/english/es/pubs/internships.php.

Patel v. Bell Mobility Inc., [2013] ON L.R.B. 52247

Perlin, Ross. 2011. Intern Nation: How to Earn Nothing and Learn Little in the Brave New Economy.

London: Verso.

Reddit. 2013. Hootsuite is Hiring Unpaid Interns, This is Illegal in BC. Accessed May 28, 2014. http://www.reddit.com/r/vancouver/comments/1bqytv/hootsuite is hiring unpaid interns this is/.

Sandhu v Brar, 2013 ON LRB 43024.

Sattler, Peggy. 2014. NDP MPP Continues Fight to Stop Exploitative Internships. Accessed September 7, 2014. http://peggysattler.ca/ndp-mpp-continues-fight-to-stop-exploitative-internships/.

Siebert, Sabina and Fiona Wilson. 2013. All Work and No Pay: Consequences of Unpaid Work in the Creative Industries. Work, Employment and Society 27 (4): 711-721.

Students Against Unpaid Internship Scams. 2014. Taking Action on Unpaid Internships: Pre-Budget Submission. Accessed May 24, 2014. http://payyourinterns.files.wordpress.com/2014/02/prebudget.pdf.

Vosko, Leah. 2006. Precarious Employment: Understanding Labour Market Insecurity in Canada. Montreal and Kingston: McGill-Queen's University Press.

Youth Alliance for Progress. 2013. Ontario: Stop Unpaid Internships. Accessed November 29, 2013. http://www.change.org/en-CA/petitions/ontario-stop-unpaid-internships.

\section{About the Author}

William Webb

William Webb is a student at Wilfrid Laurier University in Honours Communication Studies and Philosophy. He is also Editor-In-Chief for the Laurier Undergraduate Journal of the Arts, Vice President of Internal Affairs for Laurier's Faculty of Arts Student Society, and a student representative to Laurier's Divisional Council of the Faculty of Arts. 